\title{
DREAM: a distributed model for runoff, evapotranspiration, and antecedent soil moisture simulation
}

\author{
S. Manfreda ${ }^{1,3}$, M. Fiorentino ${ }^{1}$, and V. Iacobellis ${ }^{2}$ \\ ${ }^{1}$ Dipartimento di Ingegneria e Fisica dell'Ambiente (DIFA), Università degli Studi della Basilicata, via dell'Ateneo Lucano \\ 10, 85100, Potenza, Italia \\ ${ }^{2}$ Dipartimento di Ingegneria delle Acque e di Chimica (DIAC), Politecnico di Bari, via E.Orabona 4, 70125, Bari, Italia \\ ${ }^{3}$ Department of Civil and Environmental Engineering, Princeton University, Princeton, NJ 08540, USA
}

Received: 17 November 2004 - Revised: 3 February 2005 - Accepted: 16 February 2005 - Published: 23 March 2005

\begin{abstract}
The paper introduces a semi-distributed hydrological model, suitable for continuous simulations, based upon the use of daily and hourly time steps. The model is called Distributed model for $\underline{\text { Runoff, }}$ Evapotranspiration, and Antecedent soil Moisture simulation (DREAM). It includes a daily water budget and an "event scale" hourly rainfall-runoff module. The two modules may be used separately or in cascade for continuous simulation. The main advantages of this approach lay in the robust and physically based parameterization, which allows use of prior information and measurable data for parameter estimation.

The proposed model was applied over four medium-sized basins in southern Italy, exhibiting considerable differences in climate and other physical characteristics. The capabilities of the two modules (daily and hourly) and of the combined runs were tested against measured data.
\end{abstract}

\section{Introduction}

Distributed hydrological modelling of floods and water balance at basin scales provides knowledge and tools of increasing utility in water resources management. Models are increasingly used in order to simulate scenarios in catchment management, to complete or extend data sets (such as flood series), to evaluate the impacts of external forces (land use or climate change) and to fully understand the hydrological processes. In the hydrological literature many simulation models are available: TOPMODEL (Beven and Kirkby, 1979; Sivapalan et al., 1987), THALES (Grayson et al., 1995), TOPKAPI (Ciarapica and Todini, 2002) and many others; selecting the "best" one always involves a balance between data requirements and cost of model implementation.

Nevertheless, many other issues still challenge the scientist and the engineer-hydrologist. For instance the endemic lack of reliable data for calibration-validation of models, the equifinality in distributed modelling raised by Beven (1993), the upscaling and downscaling of hydrological models, the optimization of model parameterization, the exploitation of Geographic Information Systems (GIS), the identification of breakthrough technologies that are expected to improve hydrologic modelling. As highlighted in the Science and Implementation plan of PUB (IAHS Decade on Predictions in Ungauged Basins - Sivapalan et al., 2003), what above mentioned may be included in the general research on reduction of uncertainty of the hydrological prediction. Such research should develop as far as possible from blind trial and error procedures and as much as possible through the understanding of the physical process involved in the basins and the identification of processes which are dominant or controlling at different time and space scales, with reference to climate, local conditions, data requirements and type of application.

In the present paper we propose a semi-distributed model which tries to match accuracy, physical consistency and numerical efficiency. DREAM (Distributed model for Runoff, Evapotranspiration, and Antecedent soil Moisture simulation) has a parsimonious structure that fairly accomplishes the required balance between available data and computational costs. It operates at two time scales: daily and hourly. In principle, daily simulations are performed with the aim of evaluating the soil moisture conditions to be considered as initial conditions for the hourly module. The code, written in MatLab, is available online: www.princeton.edu/ $\sim$ manfreda/ DREAM.

The following sections provide a detailed description of the model along with examples of model application and validation. Moreover, a strategy for parameter calibration is suggested in order to exploit as much as possible daily data. The perspective of such approaches leads to the design of a continuous simulation scheme. 


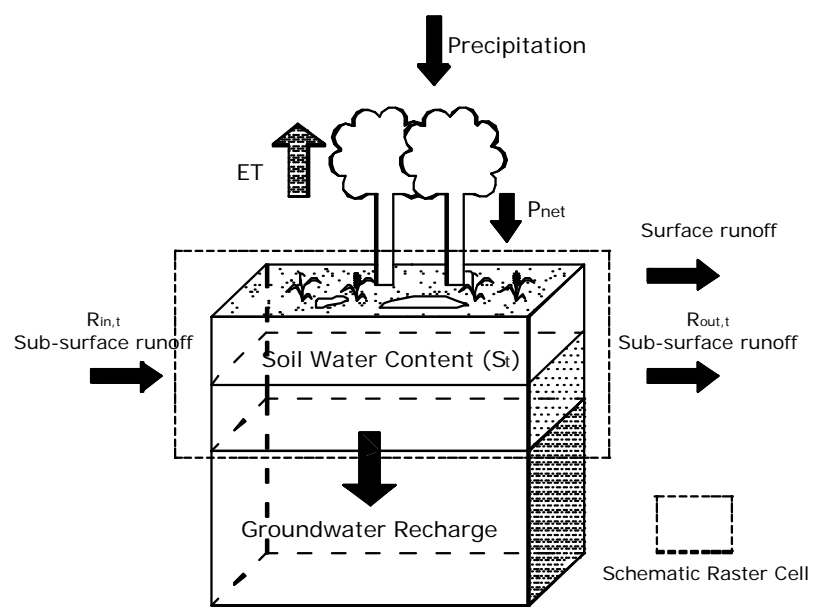

Fig. 1. In-coming and out-going fluxes in a single grid-cell. The cell represents the control volume of the water balance equation.

\section{The model}

DREAM model includes two sub-models operating at distinct time scales. Daily-DREAM (D-DREAM) model is mainly designed to reproduce daily runoff and soil dynamics. When a given threshold of rainfall is exceeded, a different module (Hourly-DREAM, in the following H-DREAM), reproducing the flood event at an hourly step, becomes operative. DREAM simulations are compound by the alternation of D-DREAM and H-DREAM runs or otherwise the two models may be applied separately. In both cases, the hydrological processes are computed on a grid-based representation of the river basin. Data concerning vegetation coverage, soil texture, local slope, etc., are required, for each cell.

The cell water balance is sketched in Fig. 1; canopy cover determines the amount of rainfall intercepted by vegetation before hitting the soil surface, throughfall (precipitation minus interception) is initially stored in surface depressions. Net precipitation (throughfall minus depression storage) is then subdivided in surface runoff and infiltration into the soil. Soil water content is redistributed within river sub-basins according to the morphological structure of the basin. Groundwater recharge is obtained as cell percolation through the vadose zone and is routed as a global linear reservoir. More details will be provided in the following sections of this paper.

\subsection{Rainfall interception and surface depression storage}

The amount of canopy interception, although negligible during the extreme events, is an important term of the water balance. On the annual scale it may be responsible for losses reaching $10 \%-20 \%$ of the total precipitation (Chang, 2003). Interception is modelled as a simple bucket of limited capacity $w_{s c}$, and according to Dickinson (1984):

$w_{s c}=0.2 L A I(\mathrm{~mm})$

where: $L A I$ is the Leaf Area Index.
The canopy water content is governed by a balance equation:

$\frac{\Delta w_{c}}{\Delta t}=p_{v}-e_{w c}$

where $p_{v}$ is the interception rate and $e_{w c}$ is the direct evaporation rate.

Direct evaporation of water from the canopy is assumed proportional to the wet canopy ratio $w_{w c}$, according to Famiglietti and Wood (1994):

$e_{w c}=\left(w_{c} / w_{s c}\right)^{2 / 3} e_{w c t}$ if $w_{c}>0$

where: $\left(w_{c} / w_{s c}\right)^{2 / 3}$ represents the ratio of wet canopy (Deardorff, 1978) and $e_{w c t}$ is the potential evaporation rate from the entire canopy.

Surface depression storage $w_{d e p}$ produces a rainfall loss $p_{d e p}$ that depends on the local characteristics of slope, land use, and soil type. The amount of water that is stored in the surface depressions is ponded to evaporate or be infiltrated later; then, $p_{d e p}$ depends on the evaporation $e_{0}[\mathrm{~L}]$ from water surface and the infiltration $i_{D}$ :

$\frac{\Delta w_{d e p}}{\Delta t}=p_{d e p}-e_{0}-i_{D}$

where the rainfall loss $p_{d e p}$ and the infiltration $i_{D}$ into the ground are found as follows:

$p_{\text {dep }}= \begin{cases}P_{t}-p_{v} & \text { if } P_{t}-p_{v}<\left(w_{\max }-w_{\text {dep }}\right) \\ w_{\max }-w_{\text {dep }} & \text { if } P_{t}-p_{v} \geq\left(w_{\max }-w_{\text {dep }}\right)\end{cases}$

$i_{D}= \begin{cases}w_{d e p} & \text { if } P_{t}-p_{v}=0 \\ 0 & \text { if } P_{t}-p_{v}>0\end{cases}$

$w_{\max }$ is the water storage capacity of the soil given in Table 1; throughfall, if less than the available storage capacity $\left(w_{\max }-w_{\text {dep }}\right)$, is completely stored in the surface depressions; otherwise, surface storage is equal to the available storage capacity $\left(w_{\max }-w_{\text {dep }}\right)$.

\subsection{Soil water balance}

Soil water content may be considered as a key variable in many fundamental processes that occur in a basin. The soil moisture storage in the vadose zone varies in space and time depending on rainfall, evapotranspiration, interflow and groundwater recharge. The following water balance equation is imposed at the cell scale (Fig. 1):

$S_{t+\Delta t}=S_{t}+I_{t}+R S_{t}-R G_{t}-E T_{v e g}$

where: $S_{t}=\theta_{t} D$ is the soil water content at time $t, \theta_{t}$ is the volumetric soil moisture content, $D$ is the soil depth, $I_{t}$ the infiltration into the soil surface, $E T_{\text {veg }}$ represents the water uptaken by the vegetation, $R S_{t}$ the lateral flow exchange, and $R G_{t}$ the groundwater recharge during the time step $\Delta t$.

After canopy interception and surface depression storage are deducted, net precipitation infiltrates until the saturation 
Table 1. Parameter $w_{\max }(\mathrm{mm})$ as a function of the land use, the slope and the soil type (Liu et al., 2003).

\begin{tabular}{llllllllllllll}
\hline Land Use & Slope $(\%)$ & sand & loamy sand & sandy loam & silty loam & silt & loam & $\begin{array}{c}\text { sandy clay } \\
\text { loam }\end{array}$ & $\begin{array}{c}\text { silty clay } \\
\text { loam }\end{array}$ & clay loam & sandy clay & silty clay & clay \\
\hline Forest & $<0.5$ & 8.00 & 7.50 & 7.00 & 6.50 & 6.00 & 5.50 & 5.00 & 4.50 & 4.00 & 3.50 & 3.00 & 2.50 \\
& $0.5-5$ & 6.00 & 5.63 & 5.25 & 4.88 & 4.50 & 4.13 & 3.75 & 3.38 & 3.00 & 2.63 & 2.25 & 1.88 \\
& $5-10$ & 4.00 & 3.75 & 3.50 & 3.25 & 3.00 & 2.75 & 2.50 & 2.25 & 2.00 & 1.75 & 1.50 & 1.25 \\
& $>10$ & 2.00 & 1.88 & 1.75 & 1.63 & 1.50 & 1.38 & 1.25 & 1.13 & 1.00 & 0.88 & 0.75 & 0.63 \\
\hline \multirow{2}{*}{ Grass } & $<0.5$ & 5.00 & 4.73 & 4.45 & 4.18 & 3.91 & 3.64 & 3.36 & 3.09 & 2.82 & 2.55 & 2.27 & 2.00 \\
& $0.5-5$ & 3.75 & 3.54 & 3.33 & 3.13 & 2.92 & 2.71 & 2.50 & 2.29 & 2.09 & 1.89 & 1.67 & 1.46 \\
& $5-10$ & 2.50 & 2.36 & 2.21 & 2.07 & 1.93 & 1.79 & 1.64 & 1.50 & 1.36 & 1.22 & 1.08 & 0.93 \\
& $>10$ & 1.25 & 1.17 & 1.09 & 1.02 & 0.94 & 0.86 & 0.78 & 0.70 & 0.63 & 0.55 & 0.47 & 0.39 \\
\hline Crop & $<0.5$ & 3.00 & 2.86 & 2.73 & 2.59 & 2.46 & 2.32 & 2.18 & 2.05 & 1.91 & 1.78 & 1.64 & 1.50 \\
& $0.5-5$ & 2.25 & 2.14 & 2.04 & 1.93 & 1.82 & 1.72 & 1.61 & 1.51 & 1.40 & 1.29 & 1.18 & 1.08 \\
& $5-10$ & 1.50 & 1.42 & 1.35 & 1.27 & 1.20 & 1.12 & 1.04 & 0.96 & 0.89 & 0.81 & 0.73 & 0.66 \\
& $>10$ & 0.75 & 0.70 & 0.66 & 0.61 & 0.56 & 0.52 & 0.47 & 0.42 & 0.38 & 0.33 & 0.28 & 0.23 \\
\hline Bare Soil & $<0.5$ & 1.50 & 1.45 & 1.41 & 1.36 & 1.32 & 1.27 & 1.23 & 1.18 & 1.14 & 1.09 & 1.05 & 1.00 \\
& $0.5-5$ & 1.13 & 1.09 & 1.05 & 1.01 & 0.97 & 0.94 & 0.90 & 0.86 & 0.82 & 0.78 & 0.74 & 0.71 \\
& $5-10$ & 0.75 & 0.72 & 0.69 & 0.66 & 0.63 & 0.60 & 0.57 & 0.54 & 0.50 & 0.48 & 0.45 & 0.42 \\
& $>10$ & 0.38 & 0.35 & 0.33 & 0.30 & 0.28 & 0.26 & 0.23 & 0.21 & 0.19 & 0.16 & 0.14 & 0.12 \\
\hline Impervius Area & $0.0-10$ & 1.0 & 1.0 & 1.0 & 1.0 & 1.0 & 1.0 & 1.0 & 1.0 & 1.0 & 1.0 & 1.0 & 1.0 \\
\hline
\end{tabular}

capacity of the soil $S_{\max }$ is reached. As a consequence, surface runoff $R_{t}$ and infiltration $I_{t}$ are found as:

$$
\begin{aligned}
& R_{t}=P_{n e t, t}-\left(S_{\text {max }}-S_{t-1}\right) \text { if } P_{n e t, t} \geq\left(S_{\max }-S_{t-1}\right) \\
& I_{t}=P_{n e t, t}-R_{t} \text { if } P_{n e t, t}>0
\end{aligned}
$$

where: $P_{n e t, t}=P_{t}-p_{v}-p_{d e p}$ is the net precipitation in the time step $\Delta t$ (rainfall minus interception and surface storage), $S_{\max }=\theta_{s} D$ is the soil water content at saturation and $\theta_{s}$ is the volumetric soil moisture content at saturation.

After infiltration, the soil water that locally exceeds the field capacity is redistributed within each sub-basin of Horton order immediately smaller than that of the whole basin. Such redistribution (Eq. 9) exploits the properties of the wetness index $(W)$ introduced by Kirkby (1975). $W$ describes the spatial variation of soil moisture, reflecting the tendency of water to accumulate in regions with large drainage area and relatively low local slope. As a consequence, cells with high values of $W$ may reach saturation and water in excess of saturation capacity is considered exfiltrated and contributes to runoff.

Such redistribution is introduced in the evaluation of the lateral flow exchange:

$$
R S_{t, j}=\left(\frac{W_{j} \sum_{i=1}^{N(t)} \max \left[c\left(S_{t, i}-S_{c, i}\right), 0\right]}{\sum_{i=1}^{N(t)} W_{i}}\right)-\max \left[c\left(S_{t, j}-S_{c, j}\right), 0\right]
$$

where: $R S_{t, j}$ is the subsurface lateral flow into cell $j$, $W_{i}=\ln (a / \tan \beta)$ ( $a$ is the drainage area per unit contour length and $\tan \beta$ is the local slope in the steepest descent direction) is the wetness index at cell $i, S_{t, i}$ is the soil water content at cell $i$ at time $t, S_{c, i}=\theta_{c} D$ is the soil water content at the field capacity at cell $i$ where $\theta_{c}$ is volumetric soil moisture content at field capacity, $N(t)$ is the number of cells (in any sub-basin) that at the time $t$ exceed field capacity and $c$ $\left[\mathrm{T}^{-1}\right]$ is the subsurface flow coefficient.

\subsection{Baseflow, soil losses and evapotranspiration}

Baseflow is modelled as a linear reservoir (of volume $W_{G W}$ ) that routes water percolated from all basin cells, with discharge $Q_{b}$ proportional to groundwater storage:

$Q_{b}=W_{G W} / k_{G}$

$k_{G}[\mathrm{~T}]$ is the groundwater recession constant.

Percolation through the unsaturated zone represents the aquifer recharge $R G_{t}$ and is assumed, according to Eagleson (1978), as a function of the hydraulic conductivity of soil:

$R G_{t}=K_{s}\left(\frac{S_{t}}{S_{\max }}\right)^{(2+3 m) / m}$

where: $K_{s}$ is the coefficient of permeability at saturation, and the parameter $m$ is the pore-size distribution index. This equation is highly non linear and may generate a severe overestimation of recharge if applied at daily time step. Then, eq. 11 was replaced by a simplified formula that accounts for the non-linearity in soil water content behaviour during the chosen time step $\Delta t$ (see Appendix A).

Evapotranspiration is evaluated as the sum of two components: evaporation from bare soil $e_{0}$ due to the water stored in 


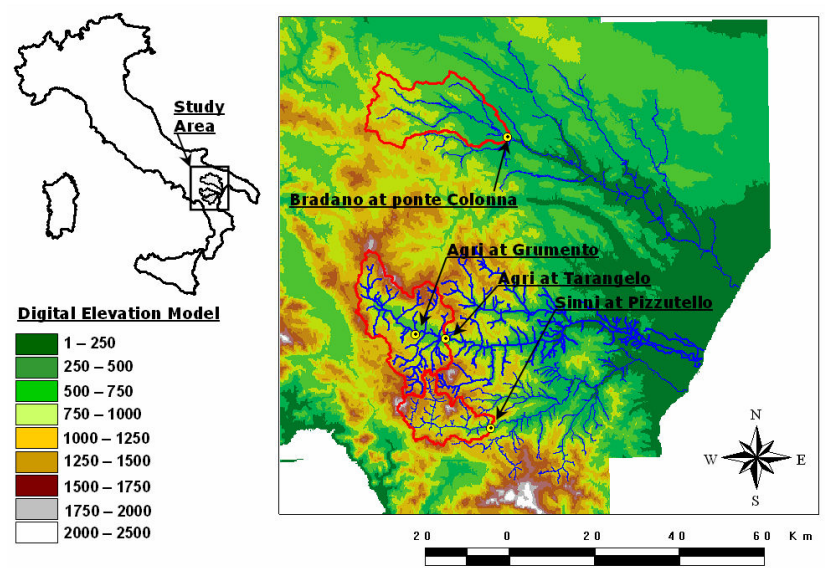

Fig. 2. Location of the study basins in Southern Italy.

surface depressions, and canopy evapotranspiration $E T_{\text {veg }}$. The distinction between vegetation cover and bare soil is based on the equation proposed by Eagleson (1982):

$M=1-e^{-\mu L A I}$

where $M$ represents the fraction of soil covered by vegetation, $\mu$ is an extinction coefficient depending on land use: 0.35 for grass, 0.45 for crops, $0.5-0.77$ for trees (Larcher, 1975).

The actual evapotranspiration from the canopy fraction $M$ of each basin cell is evaluated as:

$E T_{\text {veg }}=M \cdot \min \left(1, \frac{4}{3} \frac{S_{t}}{S_{\max }}\right) \cdot P E^{\prime}$

Evapotranspiration varies linearly between zero and the maximum rate until the relative saturation of soil is less than 0.75 (Rigon et al., 2002). When saturation exceeds this threshold the potential evapotranspiration rate $P E^{\prime}=P E-e_{w c}$ is assumed.

The actual evaporation from bare soil is evaluated by assuming that all the available water in depression storage evaporates until the potential rate is reached:

$e_{0}=(1-M) \min \left(P E, w_{d e p}\right)$

The potential evaporation $P E$ is extremely important for correct water balance estimation. It may be computed with empirical formulas like the Thornthwaite equation or otherwise with the Penman-Monteith equation when more detailed climatic data is available, like: solar radiation, vapour pressure, air temperature, wind speed, etc. This equation is highly data demanding and for this reason we prefer to use the simplified formulation of the Penman-Monteith equation proposed by the FAO (Allen et al., 1998) where daily temperature is available.

\subsection{Surface routing (hourly scale)}

At the daily time-scale, we assume, as usually accepted for small and medium sized basins, that runoff concentration
Table 2. Manning's coefficient $\left(\mathrm{s} / \mathrm{m}^{1 / 3}\right)$ as a function of the land use.

\begin{tabular}{lc}
\hline Landuse Category & Manning's coefficient \\
\hline crop or mixing farming & 0.15 \\
irrigated crop/short grass/bog marsh & 0.20 \\
mixed woodland/shrub/tall grass & 0.40 \\
evergreen/deciduous needle leaf tree & 0.40 \\
evergreen broad leaf tree & 0.60 \\
deciduous broad leaf tree & 0.80 \\
impervious area/sewer channel & 0.02 \\
streams & 0.04 \\
\hline
\end{tabular}

needs not to be modelled. Under such conditions, basin's daily streamflow is found as the sum of runoff, including exfiltration from subsurface redistribution and groundwater flow produced by a conceptual reservoir.

When daily rainfall exceeds a threshold $s$ the H-DREAM module (running at hourly scale) is activated and runoff is routed through the basin in order to obtain the flow hydrograph. The basin response function may be obtained in a GIS environment, through the extraction of topographic, topologic and hydrologic information from digital spatial data of the hydrologic system. In particular, for each cell of the basin, it is possible to define a flowpath over the hillslope and through the channel network up to the basin outlet and to evaluate the relative flowtime $f t$ on the hypothesis that local (cell) velocity is constant. The flow directions are assigned using the D8 method which assigns from each grid cell to one of its eight neighbours, either adjacent or diagonal, in the direction with steepest downward slope (O'Callaghan and Mark, 1984).

The flow velocity on the hillslopes and in the channels is determined with the Manning equation $\left(V=n^{-1} R^{2 / 3} i^{1 / 2}\right)$, where the hydraulic radius and the roughness coefficient are considered as static terrain characteristics and hence constant over time.

For each cell flowtime $f t$ is calculated as the time required for water particles to travel on the hillslope and in the channel along the flowpath that connects the cell to the basin outlet. Direct streamflow is finally calculated as the sum of the contributions from every cell, accounting for the correspondent flowtimes, as expressed in the following equation:

$Q_{s, t}=\sum_{d=1}^{\tau_{\max }} R_{t-f t}(f t=d)$

where: $Q_{s, t}$ is the overland flow, $\tau_{\max }(\mathrm{h})$ is the maximum flowtime in the basin and $d$ is the index of the sum expressed in hours.

\section{Application of DREAM}

DREAM was tested using data recorded at four different river gauged sites (Table 3), located on the main stem of three 
Table 3. Main hydrological characteristics of the basins studied.

\begin{tabular}{llllll}
\hline Basin Description & Area $\left(\mathrm{km}^{2}\right)$ & Mean elevation $(\mathrm{m} \mathrm{s.m.m.)}$ & $I_{c}$ (Climatic Index) & Annual rainfall H $(\mathrm{mm})$ & $\left(\mathrm{m}^{3} / \mathrm{s}\right)$ \\
\hline Bradano at p. Colonna & 462 & 560 & -0.08 & 680 & 202 \\
Agri at Tarangelo & 511 & 870 & 0.47 & 1100 & 189 \\
Agri at Grumento & 278 & 886 & 0.50 & 1100 & - \\
Sinni at Pizzutello & 232 & 932 & 1.26 & 1520 & 255 \\
\hline
\end{tabular}

${ }^{1}$ The climatic index, introduced by Thornthwaite (1948), is defined as the ratio $I_{c}=(H-E p) / E p$, where $H$ is the annual precipitation and $E p$ is the annual value of the potential evapotranspiration.

different rivers characterized by strong variability in climate ranging from dry to Hyperhumid moving from North-East to South-West: Bradano, Agri and Sinni (Fig. 2). These basins are all located in Basilicata, a region of Southern Italy with fairly small urbanization compared to other Italian areas. The three river basins are quite heterogeneous in geology and other physical features.

\subsection{Available database and estimation/calibration of model parameters}

The hydro-meteorological data base includes daily records of rainfall, evapotranspiration and discharge and a few rainfallrunoff events sampled hourly.

The spatial distribution of daily rainfall was accounted for by applying the Thiessen polygon method to the existing rainfall stations. For the hourly simulations rainfall records were available at fewer stations and precipitation was assumed uniform over the entire drainage area neglecting the spatial structures of the rainfall fields.

Corine land cover inventory was used to describe soil use and vegetal coverage. Changes of the vegetation states during the year were accounted for by modelling the variability of $w_{s c}$ according to monthly estimates of the Leaf Area Index $(L A I)$ based on remote sensing images. $L A I$ was evaluated by means of monthly NOAA-AVHRR images with the following equation, valid for the investigated area, (CarauxGarson et al., 1998):

$L A I=-0.39+6 N D V I$

where $N D V I=\left(R_{N I R}-R_{V I S}\right) /\left(R_{N I R}+R_{V I S}\right)$ is the Normalized Difference Vegetation Index, $R_{V I S}$ is the reflectance in the visible wavelengths $(0.58-0.68 \mu \mathrm{m})$ and $R_{N I R}$ is the reflectance in the reflective infrared wavelengths $(0.725-$ $1.1 \mu \mathrm{m})$.

The hydraulic properties of soils were assigned from the European data base HYPRES (Wösten et al., 1999) and following Carriero et al. (2004), who used a simple methodology based on correlations of soil texture with land use, morphology and geology, to downscale the HYPRES data $(1 \mathrm{~km})$ to the finer resolution $(240 \mathrm{~m})$ allowing a reliable parameterization of the soil texture of the studied basins. This allowed a priori estimates of parameters such as: porosity of soil, field capacity, soil depth, soil permeability, etc.

The Manning coefficient $(n)$ was assigned as a function of land use (see Table 2). The hydraulic radius $(R)$ was scaled along the network according to up-slope drainage area, while over the hillslope it is assumed constant and equal to $0.01 \mathrm{~m}$. Channels and channel heads were mapped as the grid cells with upstream drainage area exceeding 5 cells $\left(0.288 \mathrm{~km}^{2}\right)$. The grid resolution adopted in all simulations is $240 \mathrm{~m}$, mainly imposed by the available digital terrain model.

In particular, combining the characteristic scaling of the hydraulic radius found in the regime theory (e.g., Albertson and Simons, 1964) with the scaling of the discharge with the drainage area found in our areas (see Claps and Fiorentino, 1998), we determined that the hydraulic radius may change following a power law with exponent 0.26 :

$R=R_{\max }\left(A / A_{b}\right)^{0.26}$

where: $R_{\max }$ is a calibration parameter that determines the rate of change of $R, A_{b}$ represents the basin area at the outlet and $A$ is the drainage area at any given point of the network.

Finally, DREAM requires three parameters to be calibrated from rainfall-runoff data:

$k_{G}$ : recession constant of the linear groundwater reservoir, which was estimated by means of log-linear regression on the recession curve of daily streamflow records. In particular, it ranges from 45 (days), for Sinni and Bradano rivers, to 100 (days) for Agri;

$c$ : "subsurface flow coefficient", a function of lateral hydraulic conductivity which in principle should change within the basin according to the soil properties of the cells. It was assumed as a basin constant and was calibrated on the first year of daily streamflow data. In particular, the value which provided the minimum Root Mean Square Error (RMSE) was chosen. The analyses carried out over the considered basins indicate that the best estimate for the parameter $c$ at the daily scale was equal to $0.25\left(\mathrm{day}^{-1}\right)$ for all the considered basins. The same value was assumed as a first order approximation for $\mathrm{c}$ at the hourly scale, too. This assumption will be commented later on.

$R_{\max }$ : maximum "constant" hydraulic radius, which controls the flow routing process of surface runoff. It represents the only parameter calibrated on a single storm event (hourly simulation) and is assumed equal to $0.2 \mathrm{~m}$ at Tarangelo, the same value was used to assess the simulation of the Agri at Grumento. 

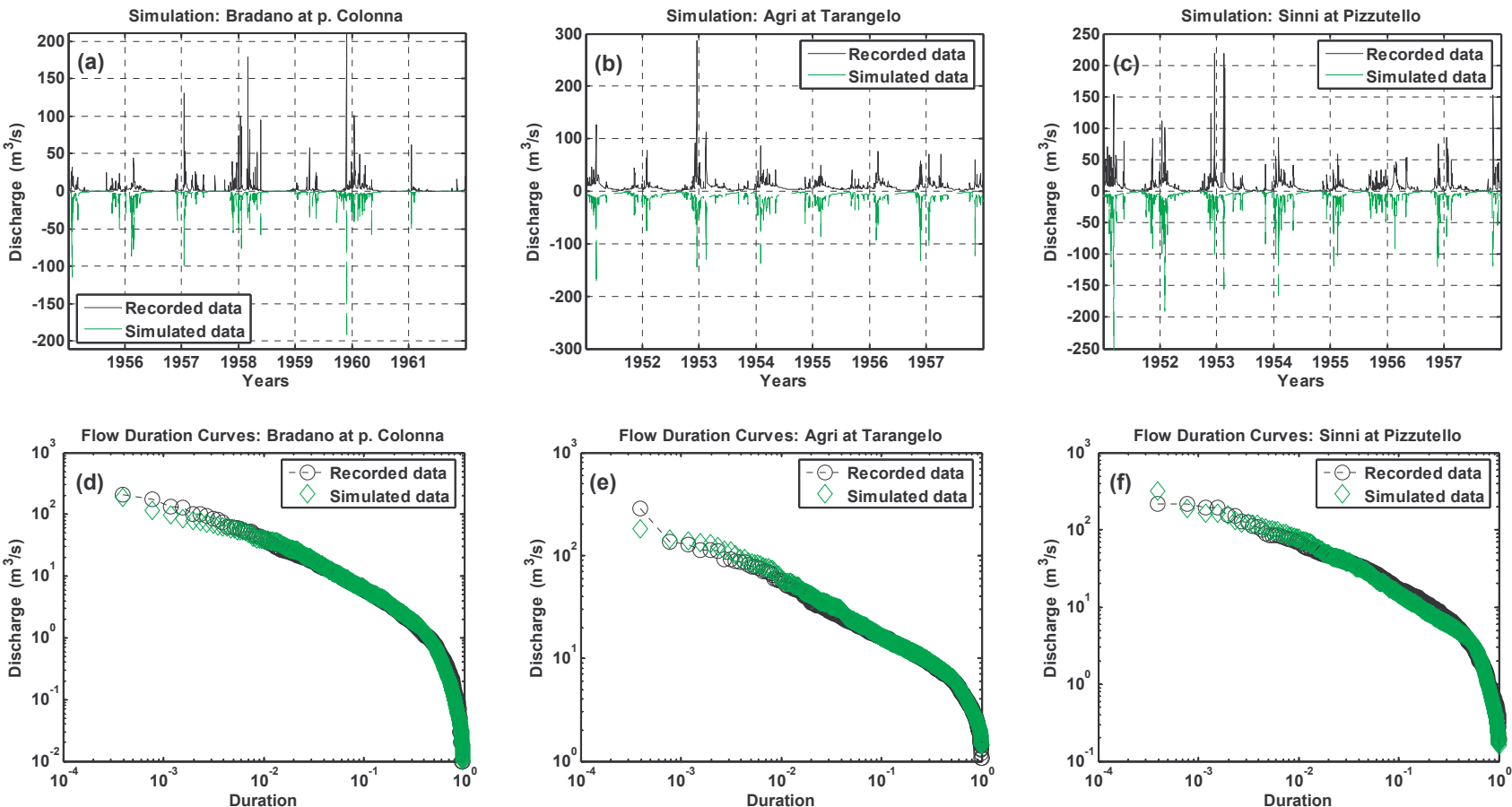

Dry - Humid - Iperhumid

Climate

Fig. 3. Comparison of simulated vs. recorded stream flow time series $(\mathbf{a}, \mathbf{b}$ and $\mathbf{c})$ and flow duration curves of the entire period $(\mathbf{d}, \mathbf{e}$ and $\mathbf{f})$.

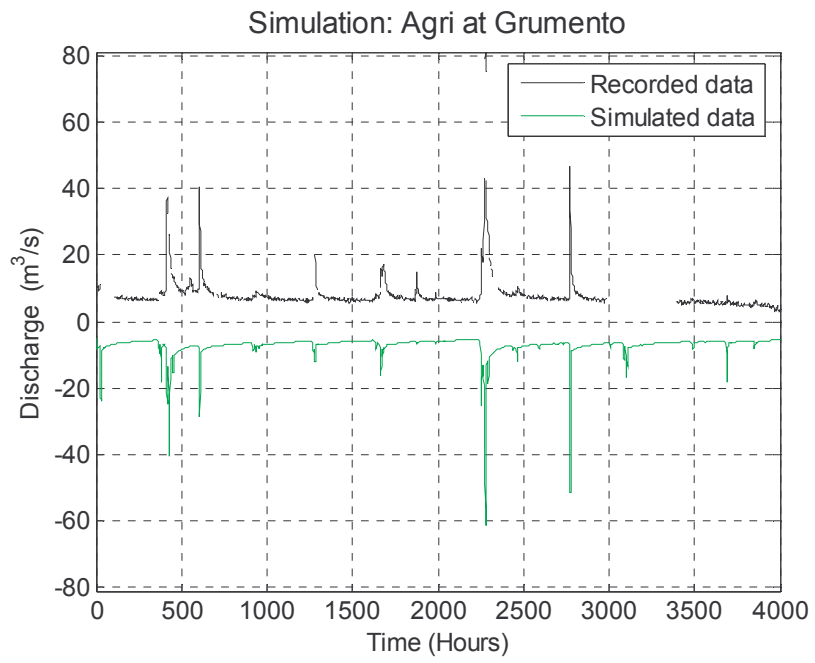

Fig. 4. Simulation of H-DREAM vs. 5 months of hourly data recorded at the gauged station of Agri at Grumento (from $31 / 12 / 2001$ to $04 / 05 / 2002$ ).

\subsection{Model runs and results}

D-DREAM runs were performed using 7 years of daily data from gauged sites at Bradano at ponte Colonna (from 1955 to 1961), Agri at Tarangelo (1951-1957), and Sinni at Pizzutello (1951-1957). In all cases, the first year was used for model calibration and the remaining six years for model validation. The soil moisture content at the beginning of the calibration period was arbitrarily assumed equal to the field capacity in all basin cells. Notwithstanding the unreliability of the choice, the length of the calibration period and the good quality of results hereafter indicates that model performances are not affected by such initial condition.

Results of D-DREAM simulations are displayed in Fig. 3, comparing simulated versus measured time series (Fig. 3a, $\mathrm{b}$ and c) and flow duration curves (Fig. 3d, e and f), both relative to the entire record of observation. In all cases, we obtained satisfactory results considering the range of climate covered. The Absolute Average Error (AAE) is consistently below $4 \mathrm{~m}^{3} / \mathrm{s}$ while the coefficient of efficiency of Nash and Sutcliffe (1970) is always above 0.83 .

The flow duration curve can represent a useful and simple descriptor of the river regimes. On the other hand the time series highlight the capability of the model to reproduce a wide range of characteristics of the observed records, including seasonality and high frequency variability. In Fig. 3 (and 4) the simulated time series are inverted in order to avoid overlap of observed and calculated discharge and to allow for a better visual comparison.

H-DREAM was tested in a continuous hourly simulation of streamflow data recorded over 5 months at Grumento on the Agri River. The gauged station is currently operative and provides hourly records of temperature, precipitation and water levels in a regular river section. Although the records have sporadic interruptions, they constitute a valuable benchmark database for model application at hourly time scale. Figure 4 shows, also in this case, a good model performance. 

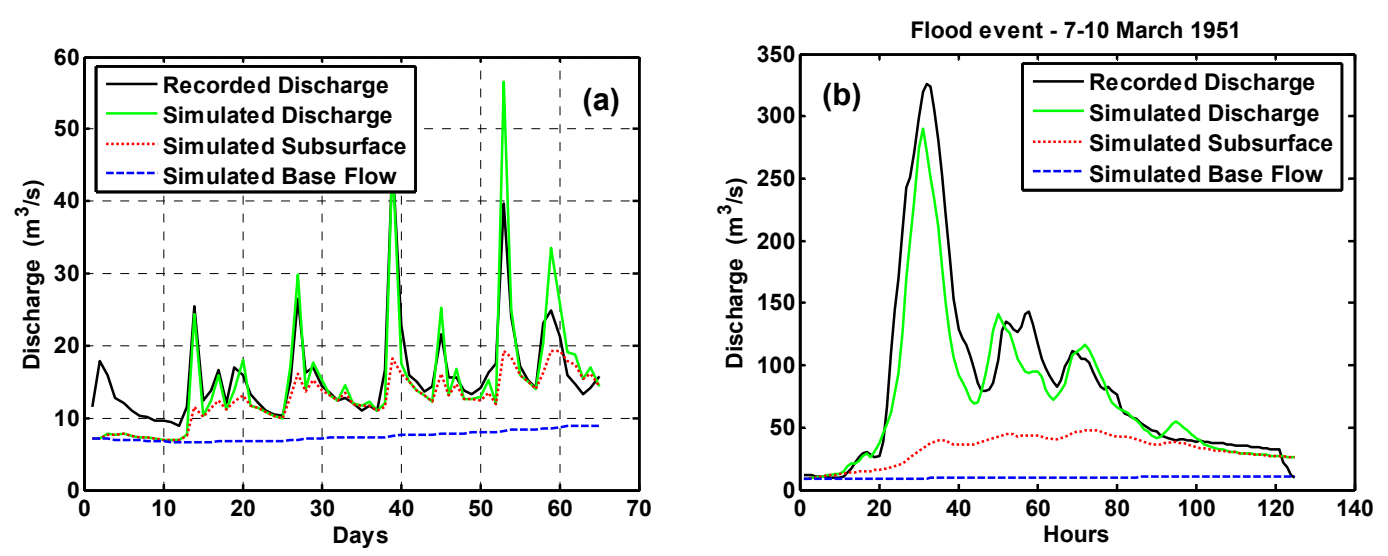

Fig. 5. Simulation of an historical flood event occurred in 1951. The hydrographs report the D-DREAM (a) and H-DREAM (b) results.

In addition, a DREAM application (daily and hourly time steps) was made to verify the model capability to reproduce a single flood event. The historical flood event was recorded in March 1951 at the Agri at Tarangelo and only five days of hourly rainfall and discharge records were available. The simulation was made with a D-DREAM run starting from the first of January 1951 with initial soil moisture state at the field capacity. Figure 5a shows that in less then 15 days, actually after the first daily rainfall event, the daily simulation is already acceptable. The good fit between H-DREAM and the hourly streamflow record, shown in Fig. 5b, testifies the reliability of the distributed initial soil moisture conditions provided by D-DREAM and assumed by H-DREAM. However, it is necessary to point out that the simulation is based on averaged rainfall inputs obtained from point measurements. Lack of detailed information on space rainfall distribution forced the assumption of uniform rainfall fields.

One may observe a good overall agreement between the simulated and the observed hydrograph data and an underestimation of about $8 \%$ of the flood peak (Fig. 5b). It is worth noting that a better fit of the peak flow could be obtained with a higher value of the parameter $c$ (coefficient of subsuperficial redistribution), which, during flood events, may be affected by an increase of the hydraulic conductivity due to preferential flows that develop at the hillslope scale. On the other hand such kind of refinement was unfeasible due to the poor quality of the rainfall input which was assumed uniform over the basin area due to the lack of information about space distribution.

\section{Final remarks}

DREAM has a simple structure which requires the calibration of a reduced number of parameters. One of the most significant features of the model is the evaluation of lateral flow exchanges by means of a redistribution function weighted by the wetness index proposed by Kirkby (1975). Such solution allows to define a global parameter called subsurface flow coefficient which is calibrated based on daily streamflow data.
DREAM also requires an accurate description of the soil coverage, texture and depth. Nevertheless the application showed that such data may be robustly drawn from large scale European databases and appropriately assimilated. In particular, vegetal coverage from Corine land cover was integrated with monthly NOAA-AVHRR images while the hydraulic properties of soils were taken from the European data base HYPRES and downscaled with a simple procedure proposed by Carriero et al. (2004).

The encouraging results obtained by the application of DREAM to real data stimulate our research toward a deeper comprehension and physical interpretation of the hydrological processes like variations of soil states, which strongly influences the hydrological basin response. Such results promote DREAM as a useful tool to understand basin behavior and to predict basin stream flow. The model structure is also suitable for continuous simulation studies that are considered, by numerous authors (e.g. Lamb and Kay, 2004; Blazkova and Beven, 2004; Manfreda et al., 2004), one of the most promising tool for flood risk prediction. Indeed, results not reported in this paper for the sake of brevity, show that DREAM, coupled with a stochastic rainfall model, is also able to fairly reproduce the observed peak flow annual maxima probability distribution (Manfreda, 2004).

\section{Appendix A: Leakage estimation}

In DREAM, groundwater recharge is estimated as the integral of the vertical leakage through the vadose zone over the time step $\Delta t$, used in the simulation. The vertical leakage may produce significant overestimation of recharge if computed directly from Eq. (11). A more accurate and numerically efficient representation of the process is provided in the following.

In the hypothesis that soil moisture variation is controlled only by the leakage loss, a hypothesis commonly accepted for soil moisture exceeding field capacity, the vadose zone 
drain balance may be approximated by the following equation:

$$
\frac{d S_{t}}{d t}=-K_{s}\left(\frac{S_{t}}{S_{\max }}\right)^{\beta}
$$

where: $\beta=(2+3 m) / m$ represents the pore disconnectedness index. The solution of the previous differential equation, given the initial condition for the soil moisture $S_{t}=S_{i n i}$, is:

$S(t)=S_{\max }\left(\frac{K_{s}(\beta-1)}{S_{\max }} t+\left(\frac{S_{\text {ini }}}{S_{\max }}\right)^{1-\beta}\right)^{1 /(1-\beta)}$

Assuming that the vertical leakage is null for soil moisture values below the field capacity, the leakage loss function during $\Delta t$ is derived:

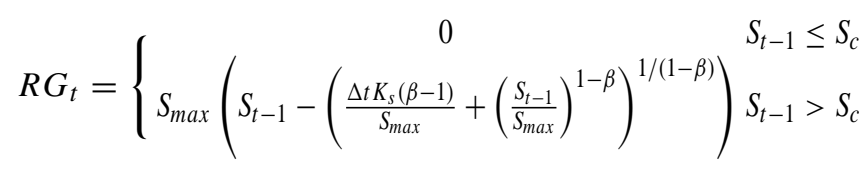

Equation (20), tested against numerical integration, provides a good approximation of the integral of Eq. (11).

Acknowledgements. The present work contains part of the results discussed in the Ph.D. thesis by S. Manfreda, whose fellowship was supported by funds of the research program $\operatorname{COS}(\mathrm{OT})$. The authors acknowledge the support of MIUR (Italian Ministry of Instruction, University and Research) through the research program Cofin 2003: "Sperimentazione idrologica a scala di bacino per la valutazione d'impatto delle dinamiche clima-suolo-vegetazione sui processi idrologici di base ed estremi".

Edited by: L. Ferraris

Reviewed by: anonymous referees

\section{References}

Albertson, M. L. and Simons, D. B.: Fluid mechanics, in: Handbook of Applied Hydrology, edited by: Chow, V. T., McGraw Hill Book Co., New York, Section 7, 7-1-7-49, 1964.

Allen, R. G., Pereira, L. S., Raes, D., and Smith, M.: Crop evapotranspiration Guidelines for computing crop water requirements, FAO Irrig. and Drain, Paper 56, Food and Agriculture Organization of the United Nations, Rome, pp. 300, 1998.

Beven, K. J. and Kirkby, M. J.: A physically-based variable contributing area model of basin hydrology, Hydrol. Sci. Bull., 24(1), 43-69, 1979.

Beven, K. J.: Prophecy, reality and uncertainty in distributed hydrological modelling, Adv. Water Resour., 16, 41-51, 1993.

Blazkova, S. and Beven, K.: Flood frequency estimation by continuous simulation of subcatchment rainfalls and discharges with the aim of improving dam safety assessment in a large basin in the Czech Republic, J. Hydrology, 292, 1-4, 153-172, 2004.

Caraux-Garson, D., Lacaze, B., Scala, F., Hill, J., and Mehl, W.: Ten years of vegetation cover monitoring with LANDSAT-TM remote sensing, an operational approach of DeMon-2 in Languedoc, France, Symposium on operational remote sensing for sustainable development, Enschede, Nederlands, 1998.
Carriero, D., Romano, N., and Fiorentino, M.: Una tecnica semplificata per la stima della distribuzione spaziale delle caratteristiche idrologiche del suolo, $29^{\circ}$ Convegno di Idraulica e Costruzioni Idrauliche, Trento, ISBN 88-7740-382-9, Editoriale Bios, 2, 723-730, 2004.

Chang, M.: Forest and precipitation, in Forest hydrology: an introduction to water and forests, Boca Raton, CRC Press, 2003.

Ciarapica, L. and Todini, E.: TOPKAPI: a model for the representation of the rainfall-runoff process at different scales, Hydrol. Proc., 16(2), 207-229, 2002.

Claps, P. and Fiorentino, M.: Rapporto di sintesi per la regione Basilicata (bacini del versante ionico), report GNDCI, 1998.

Deardorff, J. W.: Efficient prediction of ground surface temperature and moisture, with inclusion of a layer of vegetation, J. Geophys. Res., 82, 1889-1903, 1978.

Dickinson, R. E.: Modelling evapotranspiration for three dimensional global climate models, in: Climate Processes and Climate Sensitivity, edited by: Hansen, J. E. and Tekahashi, T., AGU, Washington, D.C., Geophys. Monogr. Ser., 29, 58-72, 1984.

Eagleson, P. S.: Climate, soil and vegetation, 5, A derived distribution of storm surface runoff, Water Resour. Res., 14(5), 740-748, 1978.

Eagleson, P. S.: Ecological optimality in water limited natural soilvegetation system 1 . Theory and Hypothesis, Water Resour. Res., 18(2), 325-340, 1982.

Famiglietti, J. S. and Wood, E. F.: Multi-Scale Modeling of Spatially-Variable Water and Energy Balance Processes, Water Resour. Res., 30(11), 3061-3078, 1994.

Grayson, R. B., Blöschl, G., and Moore, I. D.: Distribute parameter hydrologic modelling using vector elevation data: THALES and TAPES-C, in: Computer models of watershed hydrology, edited by: Singh, V. P., Water Resources Publications, chapter 19, 1130p, 1995.

Kirkby, M. J.: Hydrograph modelling strategies, in: Progress in Physical and Human Geography, edited by: Peel, R. F., Chisholm, M. D., and Haggett, P., Heinemann, London, 69-90, 1975.

Lamb, R. and Kay, A. L.: Confidence intervals for a spatially generalized, continuous simulation flood frequency model for Great Britain, Water Resour. Res., 40, W07501, doi:10.1029/2003WR002428, 2004.

Larcher, W.: Physiological Plant Ecology, Springer Verlag, New York, 1975.

Liu, Y. B., Gebremeskel, S., De Smedt, F., Hoffmann, L., and Pfister, L.: A diffusive transport approach for flow routing in GISbased flood modeling, J. Hydrol., 283, 1-4, 91-106, 2003.

Manfreda, S. (PhD. Thesis - Advisors: Fiorentino, M. and Mancini, I. M.): Influenza delle caratteristiche fisiche e climatiche sulla forma della coda destra della distribuzione di probabilità degli eventi estremi, University of Basilicata, 2004.

Manfreda, S., Fiorentino, M., and Iacobellis, V.: Un esempio di modellistica integrata per l'analisi dei processi che controllano la frequenza delle piene fluviali, $29^{\circ}$ Convegno di Idraulica e Costruzioni Idrauliche, Trento, ISBN 88-7740-382-9, Editoriale Bios, 2, 463-470, 2004.

Nash, J. E. and Sutcliffe, J. V.: River flow forecasting through conceptual models: Part I. A discussion of principles, J. Hydrol., 10, 282-290, 1970.

O'Callaghan, J. F. and Mark, D. M.: The Extraction of Drainage Networks From Digital Elevation Data, Computer Vision, Graphics and Image Processing, 28, 328-344, 1984. 
Rigon, R., Bertoldi, G., and Over, T. M.: GEOTOP: un modello del ciclo idrologico, Proceedings of " $28^{\circ}$ Convegno Nazionale di Idraulica e Costruzioni Idrauliche”, Potenza, 1, 303-312, 2002.

Sivapalan, M., Beven, K. J., and Wood, E. F.: On hydrological similarity 2. A scaled model of storm runoff production, Water Resour. Res., 23(12), 2266-2278, 1987.

Sivapalan, M., Takeuchi, K., Franks, S. W., Gupta, V. K., Karambiri, H., Lakshmi, V., Liang, X., McDonnell, J. J., Mendiondo, E. M., O'Connell, P. E., Oki, T., Pomeroy, J. W., Schertzer, D., Uh- lenbrook, S., and Zehe, E.: IAHS Decade on Predictions in Ungauged Basins (PUB), 2003-2012: Shaping an exciting future for the hydrological sciences, Hydrol. Sci. J., 48(6), 857-880. 2003.

Thornthwaite, C. W.: An approach toward a rational classification of climate, Geophys. Rev., 38, 55-94, 1948.

Wösten, J. H. M., Lilly, A., Nemes, A., and Le Bas, C.: Development and use of a database of hydraulic properties of European soils, Geoderma, 90, 169-185, 1999. 